\title{
IMPROVING STUDENTS' VOCABULARY MASTERY THROUGH ELECTRONIC DICTIONARY
}

\author{
Sri Yanti \\ Departement of English Education, University of Kuningan \\ Email: sriy829@gmail.com
}

APA Citation: Yanti, S. (2016). Improving students' vocabulary mastery through electronic dictionary. Indonesian EFL Journal, 2(2), 88-99

Abstract: This research is designed to investigate the use of electronic dictionary in improving students' vocabulary mastery. This quantitative research applied quasi-experimental with nonequivalent control group design by involving 65 second-grader of SMAN 1 Garawangi. There were two instruments used in this research, namely test, consisted of pretest and posttest, and questionnaire. As result, the findings showed that the mean score of experimental class on pretest was 53, and the mean score of experimental class achieved 86 after the treatment. The improvement of students' vocabulary mastery can also be seen from the level of significance (two-tailed) in paired t-test that was less than the alpha $(0.000<0.05)$. It indicated that the null hypothesis was rejected and $\mathrm{H}_{\mathrm{a}}$ was accepted which means that there was significant difference of means between pre-test and post-test of experimental class. Besides, most students endorsed ten items of questionnaire involving affective, behavioral, and cognitive aspects which means that most students in experimental class agreed that electronic dictionary can help them in improving their vocabulary mastery. Finally, the researcher concludes that the use of electronic dictionary can improve students' vocabulary mastery.

Keywords: electronic dictionary, vocabulary mastery, quasi-experimental, nonequivalent control group

\section{INTRODUCTION}

As a foreign language in Indonesia, English is taught in almost all levels of education, starting from Elementary level to university level. It aims to create people who are able to compete in international world and develop relationship with other countries. As stated by Depdikbud (1994, p. 1), "English is an internasional language that needs to be taught in order to develop knowledge, technology, and art of culture, and also to make and develop the relationship with other countries."

In English, there are four components of language skills covering listening, speaking, reading, and writing. Talking about the four language skills in English, it will be never far from vocabulary mastery. It is because without a good vocabulary mastery, someone will be difficult to speak or even understand a short text. A good vocabulary mastery is one of the most important aspects in learning foreign language because the ability of the language learners to read and to comprehend the subject is relatively determined by their vocabulary mastery (Brown, 2001). Having a lot of vocabulary helps learners to express their ideas precisely.

According to Hatch and Brown (1995, p. 1), "vocabulary refers to a list or set of words for a particular language or a list or set of words that individual speaker of a language might use." In 


\section{Sri Yanti}

Improving Students' Vocabulary Mastery through Electronic Dictionary

addition, Hatch and Brown (1995, p. 370 ) noted that vocabulary is divided into two kinds; receptive and productive vocabulary. Receptive vocabulary is a word that the students recognize and understand when it occurs in a context, but students cannot produce correctly. While, productive vocabulary is a word which the students understand, they can pronounce correctly, and use constructively in speaking and writing. Vocabulary deals with words and meaning, while mastery means the comprehensive knowledge. Thus, vocabulary mastery is comprehensive knowledge to recognize, to understand, and to produce stock of words and their meaning. In line with this, Lado (1964, p.117) argued that to clarify the idea of vocabulary, there are three levels of vocabulary which are distinguished, namely; (1) vocabulary to operate the patterns and illustrate pronunciation of the language, (2) vocabulary for communication in areas of wide currency, and (3) aesthetic and technical vocabularies.

One of the aims of teaching English is to enhance students' understanding about English vocabularies which they might find in their environment. In fact, students often find problems in learning vocabularies. Thus, teacher needs to use certain method in teaching the language to the students. In teaching process, method serves as an important factor, and should be given special attention and high priority in order to achieve the goal of teaching. Also, the teacher should decide the appropriate technique for teaching different item types.

Media can be used to help students in their study in order to make the teaching and learning process more effective and efficient. Dictionary is one of media that can be used by both teacher and students in teaching and learning process (Harmer, 2007, p. 230).
The use of dictionary is very helpful for students since they can find any kinds of words they need.

Generally, there are two kinds of dictionary, namely paper dictionary and electronic dictionary (e-dictionaries). Edictionaries maybe either online (e.g., the website Dictionary.reference.com), and can also be available as apps for smart phones (offline dictionary). Dictionary can be efficiently used to facilitate reading comprehension and vocabulary acquisition for adult learners of a second or foreign language (Aldosari \& Mekheimer, 2010).

Nowadays, the emergence of electronic dictionaries has noticeably influenced the way students learn a foreign language, even now paper dictionaries are being replaced. Paper dictionary are now being replaced since good paper-based dictionaries are too thick. That is the reason why students leave them at home, why teachers do not carry one from classroom to classroom, and why the most enthusiastic users deal with only one dictionary at a time. Besides, the use of electronic dictionaries is important in teaching and learning language since it can make students more interested and motivated in learning the language.

Furthermore, according to Zarei and Gujjar (2012), there are many advantages of using electronic dictionary in teaching vocabulary, such as electronic dictionaries are light, compact and faster than any paper dictionary, electronic dictionaries provide users with authentic recorded voice facilities for better pronunciation and provide access to large amounts of data, and psychologically, electronic dictionaries are prestigious and stylish. Thus, the researcher thought that the use of electronic dictionary was more effective than paper dictionary in improving students' vocabulary mastery. 
It is supported by the work of Zarei and Gujjar (2012) that revealed the contribution of electronic dictionary to vocabulary learning was significantly greater than the paper dictionary. In addition, Laufer and Hill (2000) found that the use of electronic dictionaries had a positive effect on learners' incidental vocabulary learning, probably attributed to the wealth of contextual information provided by electronic dictionaries, including L1 translations, L2 synonyms, and audio files providing models for pronunciation.

Thus, this study was aimed at discovering learners' use and perceptions of electronic dictionary in learning a variety tasks and their implications of the use of this electronic tool to either facilitate online learning or complement classroom-based learning. In this paper, the researcher used electronic dictionary namely Kamusku that is available as app in mobile devices. Kamusku is an Indonesian-English offline dictionary that is commonly used by students. Kamusku was chosen since it could be accessed easily by students. It was different from online dictionary in which students need internet connection to access it.

Based on explanation above, the researcher was interested in conducting a research focusing on whether or not electronic dictionary improves students' vocabulary mastery and students' attitude towards the use of electronic dictionary in improving their vocabulary mastery.

\section{METHOD}

This research was a quantitative research. Considering that this research investigated the use of electronic dictionary to improve students' vocabulary mastery, the researcher used quasi-experimental with nonequivalent control group design. Nonequivalent control group is a kind of quasiexperimental design in which "two (or more) treatment groups are pretested, administered a treatment, and posttested" (Gay, et al., 2012, p. 270). Quasiexperiments include assignment in which the experimenter cannot artificially create groups for the experiment since randomly assigning students to the two groups would disrupt classroom learning (Creswell, 2012, p. 309). The nonequivalent control group design is presented below.

Figure 1. Nonequivalent control group

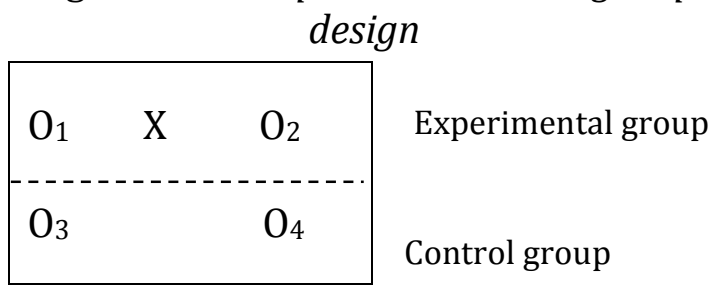

Notes:

$\mathrm{O}_{1} \quad=$ Pre-test to examine students' vocabulary mastery before treatment. $\mathrm{X} \quad=$ Giving treatment by using electronic dictionary in teaching vocabulary.

$\mathrm{O}_{2} \quad=$ Post-test to examine students' vocabulary mastery after treatment. $\mathrm{O}_{3}=$ Pre-test to examine students' vocabulary mastery in control group. $\mathrm{O}_{4} \quad=$ Post-test to examine students' vocabulary mastery without treatment.

(Gay, et al., 2012, p. 268)

Here, both experimental and control group were given the pre-test and post-test to identify the difference score before and after the treatment, while the treatment was only given to experimental group.

This research involved 315 of the second grade students at SMAN 1 Garawangi as population of the research. 
Whereas, the samples of this study were two classes chosen by obtaining purposive sampling technique. Purposive sampling happens when researcher uses his/her judgment to select a sample that they believe will provide the data needed (Fraenkel \& Wallen, 2009, p. 99). In other words, the researcher selects the sample using his/her experience of the group to be sampled (Gay, et al., p. 141). Since the researcher has taught in SMAN 1 Garawangi when the teaching practice, so the researcher used her experiences in choosing the sample of the research. Thus, the researcher chose class XI MIA 2 that consisted of 33 students to be the experimental group, and class XI MIA 3 that consisted of 32 students to be the control group.

The researcher used test and questionnaire to collect the data needed. Test, included the pre-test and post-test, was done to determine the effect of electronic dictionary towards students' vocabulary mastery, it was done before and after the treatment. While questionnaire was used to describe students' attitude towards the use of electronic dictionary in EFL classroom context.

In analyzing the data obtained, the researcher used quantitative data analysis in which the data were analyzed statistically by using SPSS 20.0. In addition, the questionnaires were analyzed with descriptive statistically.

\section{RESULTS AND DISCUSSION}

The effects of the use of electronic dictionary towards students' vocabulary mastery

The researcher used two kinds of test instrument, namely pretest and posttest instruments. Each instrument consisted of 35 questions. Before doing the pretest and posttest, these two instruments were tested in both experimental and control class. The purpose of this try-out test was to test the validity and reliability of the instruments used in this research.

Validity test was used to know whether or not the test instrument was valid and proper to be used as instrument in testing students' vocabulary mastery. As result, the researcher found thirty items were valid in both pretest and posttest instruments. It was taken by comparing between $r_{x y}$ and rtable.

Pearson coefficient correlation $\left(\mathrm{r}_{\mathrm{xy}}\right)$ were got by calculating the results of the try out test using SPSS 20.0. After getting the $r_{x y}$ of each item, the researcher compared $r_{x y}$ with $r_{\text {table }}$ to know the validity of items. If $r_{x y}$ is higher

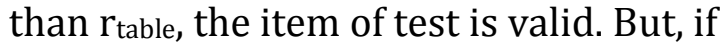
$r_{x y}$ is lower that $r_{\text {table, the item is not }}$ valid. The description of the validity test result on pretest and posttest instruments can be seen in table 1 and 2 .

Table 1. The Result of Validity Test on Pretest Instrument

\begin{tabular}{|c|c|c|c|c|c|c|c|}
\hline No.item & $\mathrm{r}_{\mathrm{xy}}$ & $\mathrm{r}_{\text {table }}$ & Validity & No.item & $\mathrm{r}_{\mathrm{xy}}$ & $\mathrm{r}_{\text {table }}$ & Validity \\
\hline 1 & 0.392 & 0.244 & Valid & 19 & 0.403 & 0.244 & Valid \\
\hline 2 & 0.525 & 0.244 & Valid & 20 & 0.414 & 0.244 & Valid \\
\hline 3 & 0.540 & 0.244 & Valid & 21 & 0.305 & 0.244 & Valid \\
\hline 4 & 0.443 & 0.244 & Valid & 22 & 0.185 & 0.244 & Not Valid \\
\hline 5 & 0.260 & 0.244 & Valid & 23 & 0.277 & 0.244 & Valid \\
\hline 6 & 0.249 & 0.244 & Valid & 24 & 0.123 & 0.244 & Not Valid \\
\hline 7 & 0.388 & 0.244 & Valid & 25 & 0.262 & 0.244 & Valid \\
\hline 8 & 0.413 & 0.244 & Valid & 26 & 0.296 & 0.244 & Valid \\
\hline 9 & 0.246 & 0.244 & Valid & 27 & 0.189 & 0.244 & Not Valid \\
\hline
\end{tabular}




\begin{tabular}{|c|c|c|c|c|c|c|c|}
\hline 10 & 0.380 & 0.244 & Valid & 28 & 0.124 & 0.244 & Not Valid \\
\hline 11 & 0.261 & 0.244 & Valid & 29 & 0.262 & 0.244 & Valid \\
\hline 12 & 0.422 & 0.244 & Valid & 30 & 0.505 & 0.244 & Valid \\
\hline 13 & 0.261 & 0.244 & Valid & 31 & 0.384 & 0.244 & Valid \\
\hline 14 & 0.590 & 0.244 & Valid & 32 & 0.097 & 0.244 & Not Valid \\
\hline 15 & 0.557 & 0.244 & Valid & 33 & 0.415 & 0.244 & Valid \\
\hline 16 & 0.379 & 0.244 & Valid & 34 & 0.395 & 0.244 & Valid \\
\hline 17 & 0.338 & 0.244 & Valid & 35 & 0.409 & 0.244 & Valid \\
\hline 18 & 0.483 & 0.244 & Valid & & & & \\
\hline
\end{tabular}

Table 2. The Result of Validity test on Posttest Instrument

\begin{tabular}{|c|c|c|c|c|c|c|c|}
\hline No.item & $\mathrm{r}_{\mathrm{xy}}$ & $\mathrm{r}_{\text {table }}$ & Validity & No.item & $\mathrm{r}_{\mathrm{xy}}$ & $\mathrm{r}_{\text {table }}$ & Validity \\
\hline 1 & 0.355 & 0.244 & Valid & 19 & 0.258 & 0.244 & Valid \\
\hline 2 & 0.264 & 0.244 & Valid & 20 & 0.274 & 0.244 & Valid \\
\hline 3 & 0.510 & 0.244 & Valid & 21 & 0.354 & 0.244 & Valid \\
\hline 4 & 0.304 & 0.244 & Valid & 22 & 0.373 & 0.244 & Valid \\
\hline 5 & 0.457 & 0.244 & Valid & 23 & 0.144 & 0.244 & Not Valid \\
\hline 6 & 0.395 & 0.244 & Valid & 24 & 0.377 & 0.244 & Valid \\
\hline 7 & 0.564 & 0.244 & Valid & 25 & 0.286 & 0.244 & Valid \\
\hline 8 & 0.525 & 0.244 & Valid & 26 & 0.233 & 0.244 & Not Valid \\
\hline 9 & 0.397 & 0.244 & Valid & 27 & 0.510 & 0.244 & Valid \\
\hline 10 & 0.268 & 0.244 & Valid & 28 & 0.418 & 0.244 & Valid \\
\hline 11 & 0.260 & 0.244 & Valid & 29 & 0.059 & 0.244 & Not Valid \\
\hline 12 & 0.313 & 0.244 & Valid & 30 & 0.439 & 0.244 & Valid \\
\hline 13 & 0.455 & 0.244 & Valid & 31 & 0.507 & 0.244 & Valid \\
\hline 14 & 0.432 & 0.244 & Valid & 32 & 0.243 & 0.244 & Not Valid \\
\hline 15 & 0.313 & 0.244 & Valid & 33 & 0.494 & 0.244 & Valid \\
\hline 16 & 0.174 & 0.244 & Not Valid & 34 & 0.411 & 0.244 & Valid \\
\hline 17 & 0.344 & 0.244 & Valid & 35 & 0.339 & 0.244 & Valid \\
\hline 18 & 0.259 & 0.244 & Valid & & & & \\
\hline
\end{tabular}

${ }^{*} r_{\text {table }}$ is taken from the list of $r_{\text {table }}$ distribution score with $5 \%$ and $1 \%$ level of significance.

The following table presents the scores distribution rable on significance level $5 \%$ and $1 \%$.

Based on the table above, it was accepted that the number of items in both table 1 and 2 were valid if the scores of $\mathrm{r}_{\mathrm{xy}}$ was higher than 0.244 . Thus, the ten items which were not valid in trying out pretest and posttest were omitted, so that the number of each test instrument were 30 items.

After trying the validity of test items and omitting the items that were not valid, the researcher tried the reliability of each test (30 items of pretest and posttest). The result of reliability test was shown in table 3 and 4.

Table 3. Reliability Statistics of Pretest

\begin{tabular}{|c|c|}
\hline Cronbach's Alpha & N of Items \\
\hline .775 & 30 \\
\hline
\end{tabular}

Table 4. Reliability Statistics of Posttest

\begin{tabular}{|c|c|}
\hline Cronbach's Alpha & N of Items \\
\hline .770 & 30 \\
\hline
\end{tabular}


Sri Yanti

Improving Students' Vocabulary Mastery through Electronic Dictionary

The reliability of a test was got by comparing the value of Cronbach's alpha with the minimum number of reliability 0.70 . Based on Tabel 3, it can be seen that the value of Cronbach's alpha was 0.775 . It means that the value of Cronbach's alpha was higher than the minimum number of reliability (0.70). So, it can be concluded that the 30 items used in pretest instrument were reliable.

Then, Table 4 shows that

Cronbach alpha of posttest is 0.770 . It means that the test was reliable because Croanbach alpha iwa more than 0.70 $(0.782>0.70)$. Thus, the thirty items were reliable. Thus, by the result of validity and reliability test of instrument above, it was accepted that the thirty items of pretest and posttest were valid and reliable.

After knowing that the tests were valid and reliable, the researcher conducted pretest and posttest. Both pretest and posttest were given to experimental and control class. When the pre-test was given before the treatment, the post-test was given in the last meeting after the students received the treatment. It was done in order to know the comparison of students' means score before and after receiving the treatment.

Normality distribution test was done to investigate whether or not the distribution of pretest and posttest scores in two groups were normally distributed. It was calculated before ttest. The criterion of normal distribution is when the probability is higher than the level of significance 0.05 ( $p>0.05$ ). Whereas, if the probability is lower than $0.05(\mathrm{p}<0.05)$, the distribution is not normal. The hypothesis to analyze the normality distribution of both groups on pretest are:

$\mathrm{H}_{0}$ : the score of two groups are normally distributed $(\mathrm{p}>0.05)$

$\mathrm{H}_{\mathrm{a}}$ : the score of two groups are not normally distributed $(\mathrm{p}<0.05)$

Table 5. Tests of Normality on Pretest

\begin{tabular}{|l|l|l|l|l|l|l|}
\hline & \multicolumn{3}{|l|}{ Kolmogorov-Smirnov a } & \multicolumn{4}{l|}{ Shapiro-Wilk } \\
\cline { 2 - 7 } & Statistic & df & Sig. & Statistic & df & Sig. \\
\hline Pre_Ex & .117 & 33 & $.200^{*}$ & .960 & 33 & .252 \\
Pre_Con & .128 & 32 & $.200^{*}$ & .933 & 32 & .048 \\
\hline
\end{tabular}

*. This is a lower bound of the true significance.

a. Lilliefors Significance Correction

Table 6. Test of Normality on Posttest

\begin{tabular}{|l|l|l|l|l|l|l|}
\hline & \multicolumn{3}{|l|}{ Kolmogorov-Smirnova } & \multicolumn{3}{l|}{ Shapiro-Wilk } \\
\cline { 2 - 7 } & Statistic & $\mathrm{df}$ & Sig. & Statistic & df & Sig. \\
\hline Post_Ex & .124 & 33 & $.200^{*}$ & .945 & 33 & .094 \\
Post_Con & .150 & 32 & .064 & .970 & 32 & .488 \\
\hline
\end{tabular}

*. This is a lower bound of the true significance.

a. Lilliefors Significance Correction

Table 5 shows that pretest in experimental and control class was normal. It can be seen from the Sig. score of experimental and control class that was 0.200 . This score was higher than the level of significance (0.05), so the distribution of pre-test scores in two classes were normally distributed. Finally, the null hypothesis was accepted since the scores of two classes were normally distributed.

In line with this, Table 6 shows that the Sig. score on posttest of experimental class was 0.200 and control 
class was 0.064 . This means that the data distribution of both groups were normally distributed because the sig scores of both groups were higher than the level of significance $(0.062>0.05)$ and $(0.064>0.05)$. Therefore, the null hypotheses was accepted.

After testing the normality of distribution test and the result of pretest was normal, the researcher conducted homogeneity of variance test.

Homogeneity of variance test was done before doing t-test. If the variances of the data collected from both groups are homogeneous, t-test can be conducted. But, if the variances are not homogeneous, the t-test cannot be conducted and it must use nonparametric test. The level of significance is 0.05 . So, if the asymp.sig $>0.05$, the null hypothesis is accepted which means that variance data of two groups is equal and homogeneous. Clear description can be seen in the following illustration:

$\mathrm{H}_{0}$ : the data of variance of the two groups are homogeneous (asymp.sig>0.05)

$\mathrm{H}_{\mathrm{a}}$ : the data of variance of the two groups are not homogeneous (asymp.sig<0.05)

Table 7. Homogeneity of Variances Test of Students' score on Pretest

\begin{tabular}{|l|l|l|l|}
\hline Levene Statistic & df1 & df2 & Sig. \\
\hline .262 & 1 & 63 & .611 \\
\hline
\end{tabular}

Table 8. Homogeneity Variances Test of Students' score on Posttest

\begin{tabular}{|l|l|l|l|}
\hline Levene Statistic & df1 & df2 & Sig. \\
\hline .763 & 1 & 63 & .386 \\
\hline
\end{tabular}

Based on Table 7, it was clear that the significance of homogeneity variance was 0.611 and it was higher than 0.05 . Besides, Table 8 also showed that the significance score was higher than the level of significance $(0.386>0.05)$. It means that the pretest and posttest scores in experimental and control class were homogeneous, so that the null hypothesis was accepted and t-test can be done.
Independent t-test was used to know the difference score between experimental and control class before the treatment. The null hypothesis is accepted between two groups if sig. 2 tailed $>0.05$. It can be seen clearly in the following criteria:

$\mathrm{H}_{0} \quad$ : there is no significance difference of means between two groups on pretest.

$\mathrm{H}_{\mathrm{a}} \quad$ : there is significance difference of means between two groups on pretest.

Table 9. Group Statistics

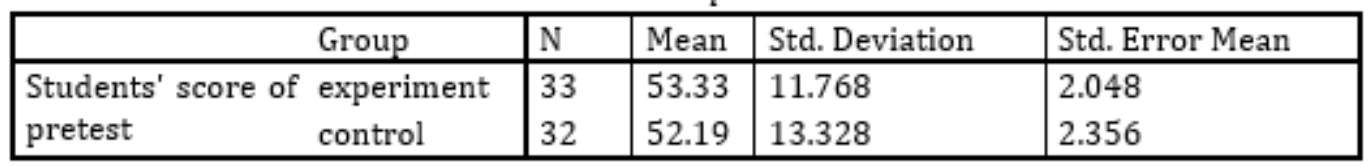


Table 10. Independent Samples Test on Pretest

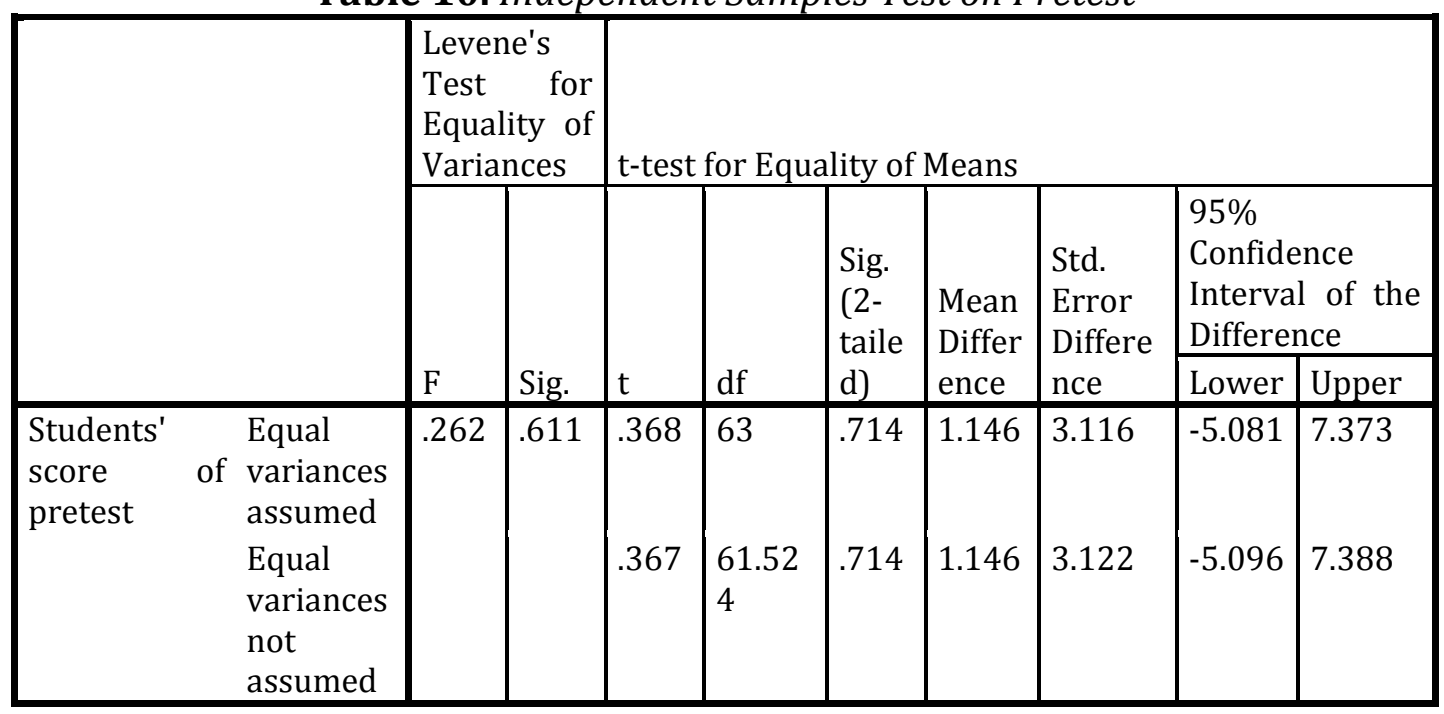

Based on table 9, the mean of pretest score in experimental class was 53.33, while in control class was 52.19. It means that both groups were not far significance difference. Then, table 10 showed that the significance score of both groups was 0.714 . It means that both groups' score were higher than 0.05 $(0.714>0.05)$. In other words, the null hypothesis was accepted because there was no significance difference between two groups. Thus, it can be concluded that the students' vocabulary mastery in both experimental and control class were same or not significantly different before the treatment.

Independent t-test on post-test is done to find out whether or not there was significant difference of means between experimental and control class after the treatment. The hypothesis formula of t-test are as follows:

$\mathrm{H}_{0}$ : there is no significant difference of means between two groups on posttest (sig.2 tailed $>0.05$ )

$\mathrm{H}_{\mathrm{a}} \quad$ : there is significant difference of means between two groups on posttest (sig.2 tailed<0.05)

Table 11. Group Statistics

\begin{tabular}{|l|l|l|l|l|l|}
\hline & Groups & $\mathrm{N}$ & Mean & Std. Deviation & Std. Error Mean \\
\hline Students' & Experiment & 33 & 86.30 & 7.548 & 1.314 \\
score of & Control & 32 & 74.75 & 5.951 & 1.052 \\
postest & Con & & & \\
\hline
\end{tabular}

Table 12. Independent Samples Test on Posttest

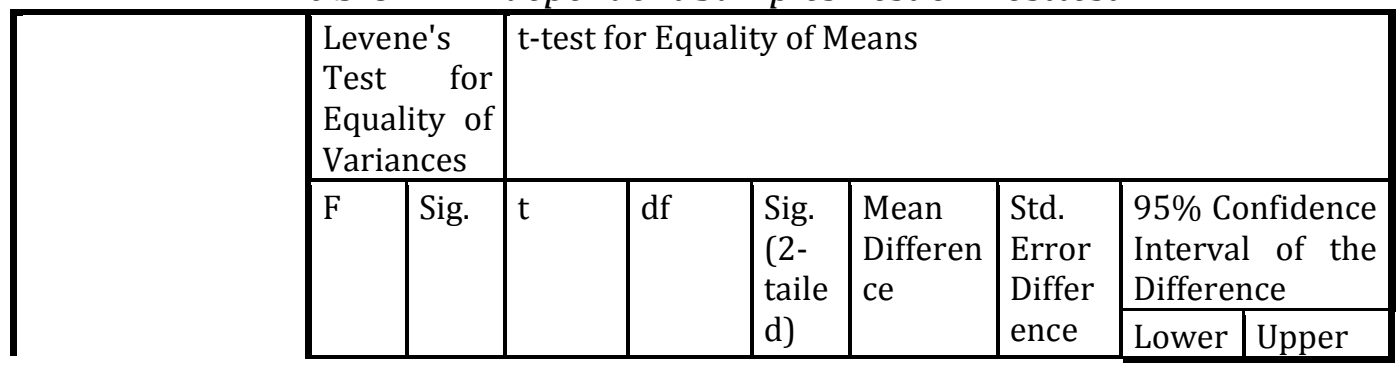




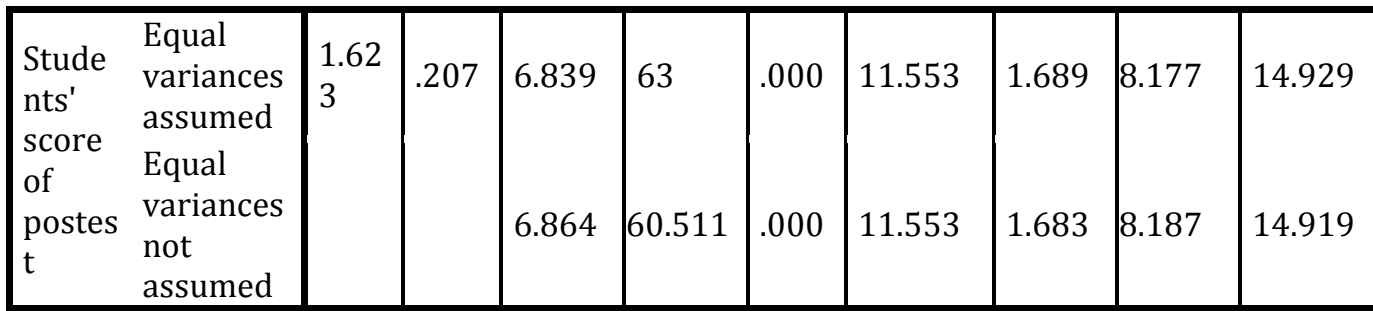

Table 11 above shows that means of both groups were significantly different in which the experimental class' mean was 86.30 and the control class' mean was 74.75. Besides, for the score of significance, it can be seen on the Table 12 that the sig (2-tailed) is 000 . This shows that the significance score was lower than the level of sig(2-tailed) 0.05 $(0.000<0.005)$. It means that the null hypothesis was rejected, because the significance score of both group was lower than 0.05 . Therefore, it can be concluded that the treatment was success since the mean score of experimental class was higher than the mean score in control class.

In the last step, the dependent ttest was done to find out the significant difference between pretest and posttest or before and after the treatment in experimental class. The hypotheses of this test are as follows:

$\mathrm{H}_{0} \quad$ : there is no significant difference of means between pre-test and post-test of experimental group (sig. 2 talied $>0.05$ )

$\mathrm{H}_{\mathrm{a}}$ : there is significant difference of means between pre-test and post-test of experimental group (sig. 2 talied $<0.05$ )

Table 13. Paired Samples Statistics

\begin{tabular}{|ll|l|l|l|l|}
\hline & & Mean & N & Std. Deviation & \multicolumn{1}{|c|}{$\begin{array}{c}\text { Std. Error } \\
\text { Mean }\end{array}$} \\
\hline \multirow{2}{*}{ Pair 1 } & Pre. ex. & 53.33 & 33 & 11.768 & 2.048 \\
& Post. ex. & 86.30 & 33 & 7.548 & 1.314 \\
\hline
\end{tabular}

Table 14. Paired Samples Test

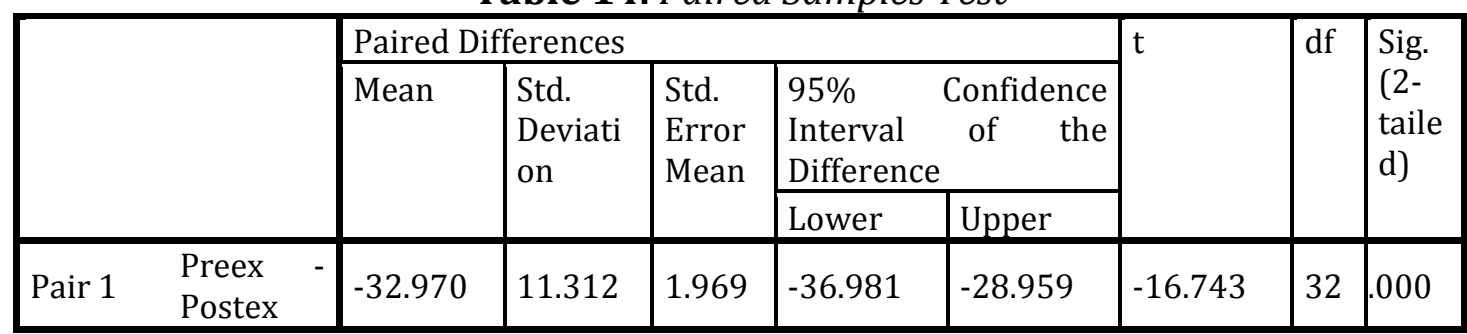

The data in Table 13 shows that the students' mean score in experimental class improved after they were given the treatment. It can be seen from the mean score of the experimental students on pretest that was 53.33 before the treatment, while the mean of students' posttest improved became 86.30 after the treatment (53.33>86.30).
Then, based on the Table 14, the $\operatorname{sig}(2$-tailed) was lower than the significance level $(0.000<0.05)$. This indicates that the null hypothesis was rejected and $\mathrm{H}_{a}$ was accepted which means that there was significant difference of means between pretest and posttest of experimental class. In other words, the use of electronic dictionary 


\section{Sri Yanti}

Improving Students' Vocabulary Mastery through Electronic Dictionary

can improv students' vocabulary mastery.

\section{The students' attitudes toward the} implementation of product and process based approach combination in EFL writing classroom

This section describes the students' attitude towards the use of electronic dictionary in improving students' vocabulary mastery. Questionnaire was an instrument in which the students were asked to answer some questions by choosing one of the options provided. The questionnaire has been tested for its validity and reliability before it was used. The result of the questionnaire analysis is presented in the following table.

Table 15. The Result of Questionnaire

\begin{tabular}{|c|c|c|c|c|c|c|}
\hline \multirow{2}{*}{$\begin{array}{c}\text { Attitude } \\
\text { Component }\end{array}$} & \multirow[t]{2}{*}{ Statements } & \multicolumn{5}{|c|}{ Answers } \\
\hline & & $\begin{array}{c}\text { Strongly } \\
\text { Agree } \\
\text { (5) }\end{array}$ & $\begin{array}{l}\text { Agree } \\
(4)\end{array}$ & $\begin{array}{c}\text { Undecided } \\
\text { (3) }\end{array}$ & $\begin{array}{c}\text { Disagree } \\
\text { (2) }\end{array}$ & $\begin{array}{c}\text { Strongly } \\
\text { Disagree } \\
(1)\end{array}$ \\
\hline \multirow{3}{*}{ Affective } & 1 & $\begin{array}{c}12 \\
36 \%\end{array}$ & $\begin{array}{c}17 \\
52 \%\end{array}$ & $\begin{array}{c}3 \\
9 \%\end{array}$ & $\begin{array}{c}1 \\
3 \%\end{array}$ & - \\
\hline & 2 & $\begin{array}{c}10 \\
30 \%\end{array}$ & $\begin{array}{c}14 \\
42 \% \\
\end{array}$ & $\begin{array}{c}7 \\
21 \% \\
\end{array}$ & $\begin{array}{c}2 \\
6 \% \\
\end{array}$ & - \\
\hline & 3 & $\begin{array}{c}9 \\
27 \%\end{array}$ & $\begin{array}{c}15 \\
45 \%\end{array}$ & $\begin{array}{c}8 \\
24 \%\end{array}$ & $\begin{array}{c}1 \\
3 \% \\
\end{array}$ & - \\
\hline \multirow{3}{*}{ Behavioral } & 4 & $\begin{array}{c}4 \\
12 \%\end{array}$ & $\begin{array}{c}12 \\
36 \%\end{array}$ & $\begin{array}{c}10 \\
30 \%\end{array}$ & $\begin{array}{c}2 \\
6 \%\end{array}$ & $\begin{array}{c}5 \\
15 \%\end{array}$ \\
\hline & 5 & $\begin{array}{c}6 \\
18 \%\end{array}$ & $\begin{array}{c}15 \\
45 \%\end{array}$ & $\begin{array}{c}9 \\
27 \%\end{array}$ & $\begin{array}{c}3 \\
9 \%\end{array}$ & - \\
\hline & 6 & $\begin{array}{c}7 \\
21 \% \\
\end{array}$ & $\begin{array}{c}12 \\
36 \% \\
\end{array}$ & $\begin{array}{c}9 \\
27 \% \\
\end{array}$ & $\begin{array}{c}5 \\
15 \% \\
\end{array}$ & - \\
\hline \multirow{4}{*}{ Cognitive } & 7 & $\begin{array}{c}10 \\
30 \% \\
\end{array}$ & $\begin{array}{c}13 \\
39 \% \\
\end{array}$ & $\begin{array}{c}9 \\
27 \% \\
\end{array}$ & $\begin{array}{c}1 \\
3 \% \\
\end{array}$ & - \\
\hline & 8 & $\begin{array}{c}8 \\
24 \% \\
\end{array}$ & $\begin{array}{c}15 \\
45 \% \\
\end{array}$ & $\begin{array}{c}9 \\
27 \%\end{array}$ & $\begin{array}{c}1 \\
3 \% \\
\end{array}$ & - \\
\hline & 9 & $\begin{array}{c}9 \\
27 \% \\
\end{array}$ & $\begin{array}{c}14 \\
42 \% \\
\end{array}$ & $\begin{array}{c}6 \\
18 \% \\
\end{array}$ & $\begin{array}{c}4 \\
12 \% \\
\end{array}$ & - \\
\hline & 10 & $\begin{array}{c}10 \\
30 \% \\
\end{array}$ & $\begin{array}{c}17 \\
52 \% \\
\end{array}$ & $\begin{array}{c}2 \\
6 \% \\
\end{array}$ & $\begin{array}{c}4 \\
12 \% \\
\end{array}$ & - \\
\hline
\end{tabular}

Based on the table above, it can be concluded that most students agreed that electronic dictionary helped them in learning vocabulary. It was got from students' answer where they promoted statements like "I like learning vocabulary by using electronic dictionary," "I feel excited when learning vocabulary by using electronic dictionary," and "Learning vocabulary became fun activity after I use electronic dictionary." As it is shown in attitude component especially in affective aspect,
$52 \%$ of the students agreed that they like learning vocabulary by using electronic dictionary. The students also agreed that they felt excited when learning vocabulary by using electronic dictionary with percentage $42 \%$. Then, $45 \%$ of them agreed that the learning process became fun after learning vocabulary by using electronic dictionary.

In behavioral aspect, it can be seen that the students endorsed these following statements; "I will follow the learning process if the teacher uses the 
electronic dictionary in learning vocabulary," "I tried to be active if the teacher teaches by using electronic dictionary," and "I can use vocabulary properly after learning by using electronic dictionary." As it is described in table $4.22,36 \%$ of the students agreed that they will follow the learning process if the teacher uses electronic dictionary in learning vocabulary. The students also agreed that they will be active if the teacher teaches by using electronic dictionary with percentage $45 \%$. Then, $36 \%$ students agreed that they can use vocabulary properly after using electronic dictionary.

Finally, in cognitive aspect, 39\% of the students promoted the statement "Electronic dictionary is appropriate for learning vocabulary." $45 \%$ of them agreed that they learnt effectively when the teacher provided the material of vocabulary by using electronic dictionary. Then, the students agreed that their vocabulary mastery improved after learning by using electronic dictionary with percentage $42 \%$. Last, $52 \%$ of them agreed that electronic dictionary can help them to understand all about vocabulary. It means that more than half of the samples in experimental class agreed that electronic dictionary can help them in improving their vocabulary mastery.

\section{CONCLUSION}

As the result of this research, it could be concluded that electronic dictionary improves students' vocabulary mastery at second grader in SMAN 1 Garawangi. Although the students sometimes faced several obstacles in learning vocabulary, such as finding appropriate synonym or antonym for several vocabularies and applying those vocabularies appropriately in a sentence, but the use of electronic dictionary was revealed to be helpful for them to improve their vocabulary mastery. The conclusion was supported by the result of dependent ttest in experimental class which showed that the mean score of experimental class on pretest was 53, and the mean score of experimental class achieved 86 after the treatment. Besides, as it could be seen in table 4.19, the sig(2-tailed) was lower than the significance level $(0.000<0.05)$. It indicated that the null hypothesis was rejected and $\mathrm{H}_{\mathrm{a}}$ was accepted which means that there was significant difference of means between pre-test and post-test of experimental class. In other words, the use of electronic dictionary can improve students' vocabulary mastery.

Then, based on the result of the questionnaire, most students (52\% students, $42 \%$ students, and $45 \%$ students) agreed to the three statements given in affective aspect. In behavioral aspect, the three statements were also endorsed by $36 \%$ students, $45 \%$ students, and $36 \%$ students who agreed to the statements given. Then, for the cognitive aspect, from four statements given, $39 \%$ students, $45 \%$ students, $42 \%$ students, and $52 \%$ agreed to those four statements. Therefore, the researcher concluded that most students in experimental class agreed that electronic dictionary can help them in improving their vocabulary mastery.

\section{REFERENCES}

Aldosari, H., \& Mekheimer, M. (2010). Utilization of English-English online dictionaries for enhancing culturespecific translation skills in college students. Paper presented at the International Conference of Suleyman Demirel University. Building Cultural Bridges: Integrating Languages, 


\section{Sri Yanti}

Improving Students' Vocabulary Mastery through Electronic Dictionary

Linguistics, Literature and Translation into Education. Almaty, Kazakhstan.

Brown, H. D. (2001). Teaching by principles: An interactive approach to language pedagogy. Englewood Cliffs: Prentice Hall.

Creswell, J. W. (2012). Educational research (4th ed.). Boston, MA: Pearson Education, Inc.

Depdikbud. (1994). Pembangunan pendidikan dan kebudayaan menjelang era tinggal landas. Jakarta: Depdikbud.

Fraenkel, J. R., \& Wallen, N. E. (2009). How to design and evaluate research in education (7th ed.). New York: McGraw Hill Company, Inc.

Gay, L. R., Mills, G. E., \& Airasian, P. W. (2012). Educational research: Competencies for analysis and applications (10 ${ }^{\text {th }}$ ed.). Boston, MA: Pearson Education, Inc.

Harmer, J. (2007). The practice of English language teaching ( $4^{\text {th }}$ ed). Cambridge: Pearson Education Limited.
Hatch, E., \& Brown, C. (1995). Vocabulary, semantics, and language education. Cambridge: Cambridge University Press.

Lado, R. (1964). Language teaching: A scientific approach. New York: McGraw- Hill.

Laufer, B., \& Hill, M. (2000). What lexical information do L2 learners select in a CALL dictionary and how does it affect word retention? Language Learning \& Technology, 3(2), pp. 58-76. Retrieved from http://llt.msu.edu/vol3num2/lauferhill/index.html

Zarei, A. A., \& Gujjar, A. A. (2012). The contribution of electronic and paper dictionaries to Iranian EFL learner's vocabulary learning. International journal of social, science, \& education, 2(4), pp. 628. ISSN: 2223-4934. 